Article

\title{
Sustainable Block Design Process for High-Rise and High-Density Districts with Snow and Wind Simulations for Winter Cities
}

\author{
Norihiro Watanabe ${ }^{1, *}$, Tsuyoshi Setoguchi ${ }^{2}$, Kosuke Maeda ${ }^{3}$, Daiki Iwakuni ${ }^{4}$, \\ Zhiming Guo ${ }^{1}$ (D) and Takuya Tsutsumi ${ }^{5}$ \\ 1 Division of Architectural and Structural Design, Graduate School of Engineering, \\ Hokkaido University, Sapporo, Hokkaido 060-8628, Japan; burningrain1988@eis.hokudai.ac.jp \\ 2 Division of Architectural and Structural Design, Faculty of Engineering, Hokkaido University, \\ Sapporo, Hokkaido 060-8628, Japan; setoro@eng.hokudai.ac.jp \\ 3 Mitsubishi Jisho Sekkei, Inc., Chiyoda, Tokyo 100-0005, Japan; kosukemmm@gmail.com \\ 4 Takenaka Corporation, Chuo, Osaka 541-0053, Japan; d55136109daiki@gmail.com \\ 5 Northern Regional Building Research Institute, Hokkaido Research Organization, Asahikawa, \\ Hokkaido 078-8801, Japan; tutumi@hro.or.jp \\ * Correspondence: norihiro.watanabe@gmail.com; Tel.: +81-11-706-6243
}

Received: 5 October 2017; Accepted: 5 November 2017; Published: 20 November 2017

\begin{abstract}
Urban designs that consider regional climatic conditions are one of the most important approaches for developing sustainable cities. In cities that suffer from heavy snow and cold winds in winter, an urban design approach different than that used for warm cities should be used. This study presents a scientific design process (the sustainable design approach) that incorporates environmental and energy assessments that use snow and wind simulations to establish guidelines for the design of urban blocks in high-rise and high-density districts so that the impact of snow and wind can be minimized in these cities. A city block in downtown Sapporo, Japan, was used as a case study, and we evaluated four conceptual models. The four models were evaluated for how they impacted the snow and wind conditions in the block as well as the snow removal energy. Based on the results, we were able to identify the design guidelines in downtown Sapporo: an urban block design with higher building height ratio without the mid-rise part can reduce the snowdrifts and lower the snow removal energy. The proposed sustainable urban design approach would be effective in improving the quality of public spaces and reducing snow removal energy in winter cities.
\end{abstract}

Keywords: winter city; wind tunnel; urban block design; snow simulation; energy assessment

\section{Introduction}

Urban design that considers snowy and windy conditions is ideal for cities that experience severe winters (hereinafter referred to as winter cities). In traditional urban designs for winter cities, skywalks and atriums are often proposed. However, constructing these designs is expensive and a considerable amount of energy is required to heat them, which makes them less environmentally friendly. Conversely, designs that control such snowy or windy conditions can reduce the impact of these conditions and improve energy consumption in winter cities. Such designs consider, for example, where a building will be built and of what shape will it be.

Sustainable urban designs are particularly important for the downtown districts of winter cities. Downtown areas around the world have recently seen an increase in the number of high-rise and high-density developments within them. The high-rise and high-density buildings strongly affect public spaces (both streets and open spaces) as buildings with large volumes elicit large localized changes in an urban area's environmental conditions. It is therefore necessary to study and develop 
urban designs for buildings and public spaces that can minimize the impact of snow and strong winds in the downtown areas of winter cities.

Using a high-density block in downtown Sapporo, Japan, as a case study, this research proposes a method for developing climate-responsive designs for urban blocks within winter cities and provides guidelines for designing such structures. To do this, we assessed a series of high-rise and high-density blocks with a variety of urban block designs using snow and wind simulations in a wind tunnel in order to determine the effect of various urban block designs on both the snow and wind conditions in various blocks as well as the amount of energy required for snow removal. Subsequently, we developed a set of guidelines based on the assessment results and summarized the process of developing sustainable urban block designs for winter cities.

The consideration of climatic aspects is one of the most important issues in urban design. Many scientific researches and public actions were attempted for a long time [1]. Recently, detailed analysis on the climatic impact of urban design has attracted academic interest with enhancement of simulation techniques; examples include the desirable exterior design for improving outdoor thermal environment [2], developing the guidelines to enhance the ventilation performance of existing buildings with studying vernacular architecture [3], the use of air ventilation in urban areas in order to reduce the occurrence of urban heat islands [4-7], improving pedestrian comfort [8,9], and urban designs that consider the impact of sunlight and wind [10]. Most previous studies have investigated warm regions; however, winter cities require a different approach [11,12]. As such, this study is focused on cold regions and considers urban design approaches used for winter cities.

Computational fluid dynamics (CFD) and wind tunnels are popular techniques for analyzing snow and wind conditions; for example, the studies mentioned in the paragraph above all used CFD to simulate wind flows [4-12]. Additionally, Tominaga et al. [13] and Okaze et al. [14] both developed CFD models of snowdrifts around a building. CFD simulations can be helpful in visualizing the relation between an urban design and snow and wind flows; however, these simulations cannot reliably simulate the complexity and uncertainty of turbulence in real-world conditions when they are applied at an urban scale $[9,15]$. Therefore, this study uses wind tunnels to analyze the snow and wind flows around a target block.

Table 1 summarizes the main areas that both previous studies and this study focused upon when using wind tunnels. Several previous environmental assessments of building designs have only simulated wind conditions using a wind tunnel; examples include analyzing the wind flow around high-rise buildings [16], estimation of natural ventilation flow rate for a detached house with monitor roof [17] and studying the wind pressure distributions and the response of a suspended roof due to turbulence [18].

Table 1. Prior studies on the effects of snow and wind where wind tunnels were used.

\begin{tabular}{ccc}
\hline Simulation & Building Design & Urban Design \\
\hline \multirow{3}{*}{ For Only Wind } & Murota [16] & Kim, H et al. [15] \\
& Keng, X et al. [19] \\
& Kobayashi et al. [17] & Bosselmann et al. [20] \\
& Arens et al. [21] \\
\hline & Anno [22] & \\
For Wind and Snow & Smedley et al. [23] & Setoguchi et al. [27-32] \\
& Yukawa et al. [24] & Watanabe et al. [33] \\
& Mitsuhashi [25] & \\
\hline
\end{tabular}


Kim et al. [15], Meng et al. [19], Bosselmann et al. [20] and Arens et al. [21] produced useful studies of downtown San Francisco, California, United States, and they demonstrated the environmental impact of high- and mid-rise buildings using wind simulations conducted solely using a wind tunnel which compared San Francisco's wind conditions in 1985 and 2013 using a wind tunnel [15,19-21]. Kim et al. [15] suggested that the planning guidelines enacted since 1985 were effective in improving the wind comfort in public spaces. Our study applies the wind planning methods from this study to its own research on snow.

Anno [22], Smedley et al. [23], Yukawa et al. [24], Mitsuhashi [25] and Yukawa et al. [26] all conducted snow simulations using wind tunnels. These studies were suitable for determining desirable building designs and locations in relation to snow and wind conditions; however, they did not consider the design of the broader urban space.

Setoguchi et al. [27-29] and Watanabe et al. [33] all considered the urban design process, including assessments of the impact of snow and wind on winter cities. By comparing high- and mid-rise buildings in Sapporo, Japan, [30,31] found that high-rise buildings more strongly impacted the surrounding snow and wind conditions than mid-rise buildings. Setoguchi et al. [32] also proposed a method for estimating the amount of energy required for snow removal using their simulations. Setoguchi et al. [28,29] discussed about the low-rise building design and Setoguchi et al. [27,30-32] and Watanabe et al. [33] discussed about the medium-density buildings with 500-800\% Floor Area Ratio (FAR). The $500-800 \%$ FAR is equal to the current FAR in downtown Sapporo. However, the redevelopment projects with high-rise and high-density buildings are recently increasing along with the population concentration in the downtown area in Sapporo. Such high-rise and high-density buildings strongly affect the environment of the public spaces, because the structures are generally planned in high-traffic areas and the large volumes of the buildings cause very large changes in the environmental situations.

Based on the findings of these previous studies, our study focuses on high-rise and high-density buildings, considering both the impact of snow and wind in urban block designs and the energy required for snow removal before concluding with a set of guidelines on the urban block design process.

\section{Method}

\subsection{Sustainable Urban Design Approach}

Figure 1 shows a proposed sustainable design approach for winter cities that incorporates the environmental and energy assessments considered in this study. In recent years, the importance of environmental and energy assessments has been recognized and specific assessment procedures have been integrated and enforced in urban planning and architectural design. Most of these assessments, however, are performed after finalizing the planned building function and form. Any required changes that result from these assessments may be described as incidental. The proposed sustainable design approach for winter cities assesses the environment and energy in tandem with the planning process and reflects assessment results directly in the urban design.

As shown in Figure 1, this paper describes the first step in developing a new sustainable urban design approach. It considers urban block designs that incorporate environmental and energy assessments using snow and wind simulations and reports on the effectiveness of the new approach. 


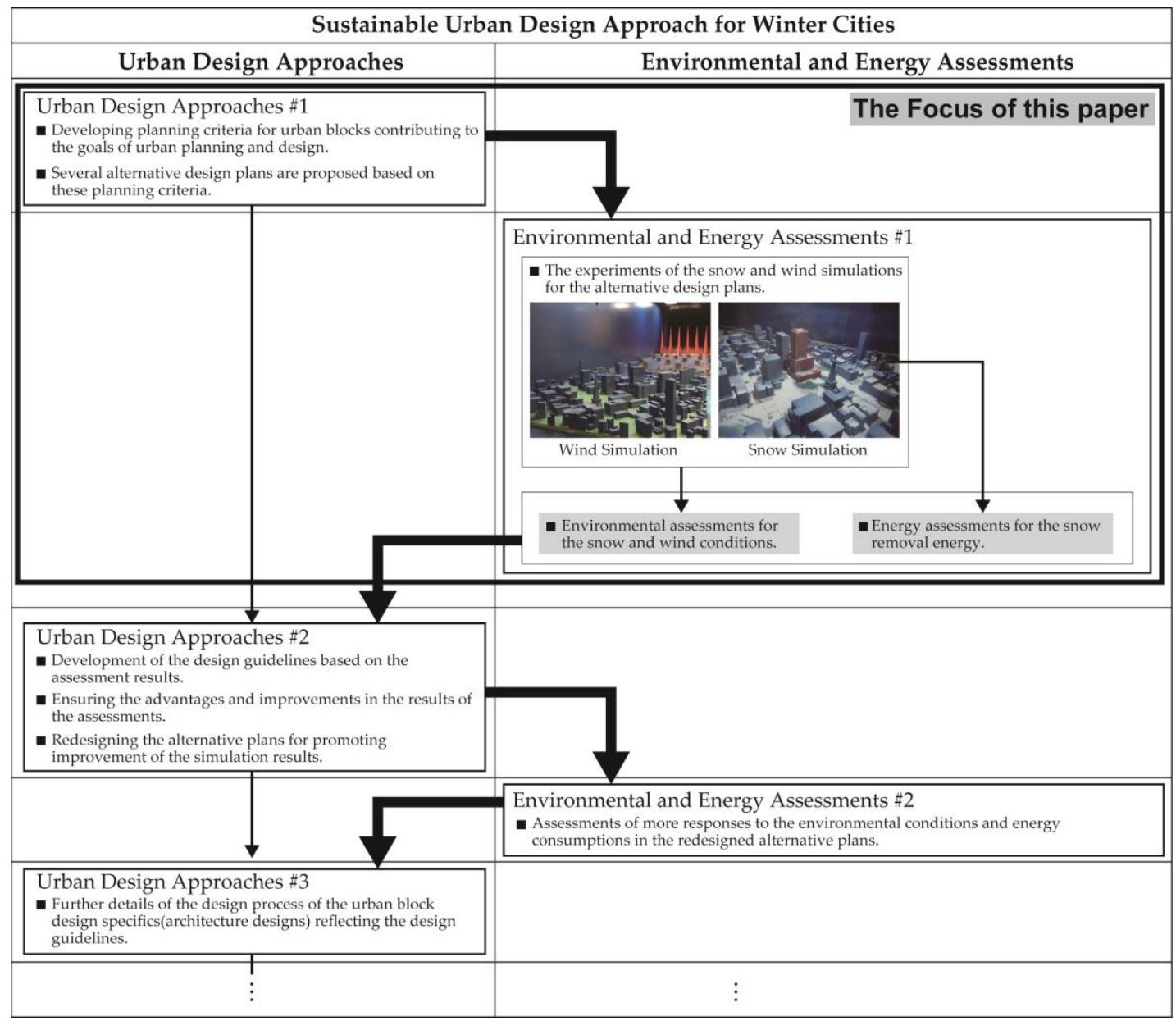

Figure 1. Sustainable urban design approach for winter cities that incorporates environmental and energy assessments.

\subsection{Snow Simulation}

Snow simulation tests were performed using the boundary-layer wind tunnel at the Hokkaido Research Organization (HRO). The wind tunnel is 7-m long, 150-cm wide, and 70-cm high as shown in Figure 2a. Snowfall was replicated using compressed air that blew model snow out from the windward supply nozzle. The model snow was made from a white soil powder with a moisture content of $8.5 \%$, an average diameter of $20 \mu \mathrm{m}$, and an angle of repose of $46^{\circ}$. Figure $2 \mathrm{c}$ shows the angle of repose for real snow in Hokkaido. The model snow was incrementally supplied to the wind tunnel at a rate of approximately $480 \mathrm{~g} / \mathrm{min}$; the total amount of model snow used per experiment was $10 \mathrm{~kg}$. The depth of the model snow deposited in the wind tunnel was measured using an LK500 laser that was manufactured by Keyence, Japan. The model snow was deposited over the course of approximately $20 \mathrm{~min}$, which was comparable to seven days of snowfall at $7 \mathrm{~cm}$ per day in a real environment. In the calculations, the one-week equivalent depth results were divided by seven in order to determine the average snow depth per day. The average wind speed in winter in downtown Sapporo is $2.46 \mathrm{~m} / \mathrm{s}$ (Japan Meteorological Agency, 1992-2000). The wind conditions were simulated using the velocity and turbulence intensity profiles shown in Figure $2 b$. The wind speed in the wind tunnel was set such that it would be equal to the actual average wind speed using equations previously derived by [22]. Anno [22] developed Equation (1) to determine the wind speed at some reference height given the threshold-friction speed of the particles. In Equation (1), $U_{p}$ is the real-phenomenon wind speed at some reference height, $U_{m}$ is the experiment wind-speed value at some reference height, $A_{p}$ and $A_{m}$ are constants, $U_{t p}^{*}$ is the real-phenomenon threshold-friction speed of the particles, and $U_{t m}^{*}$ 
is their experimental threshold-friction-speed value. When activated clay is used as model snow, Equation (1) is simplified as Equation (2). $U_{t p}^{*}$ was set to be $0.2 \mathrm{~m} / \mathrm{s}$ based on the observation in the winter in Hokkaido [34]. $U_{t m}^{*}$ was set to be $0.3 \mathrm{~m} / \mathrm{s}$ based on the result of the experiment using a wind tunnel [35]:

$$
\begin{aligned}
\frac{U_{p}}{U_{m}} & =\frac{A_{m} \times U_{t p}^{*}}{A_{p} \times U_{t m}^{*}} \\
\frac{U_{p}}{U_{m}} & =1.375 \frac{U_{t p}^{*}}{U_{t m}^{*}}
\end{aligned}
$$

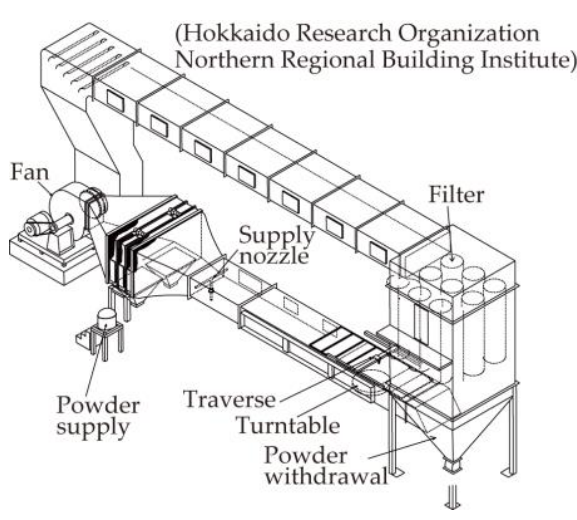

(a)

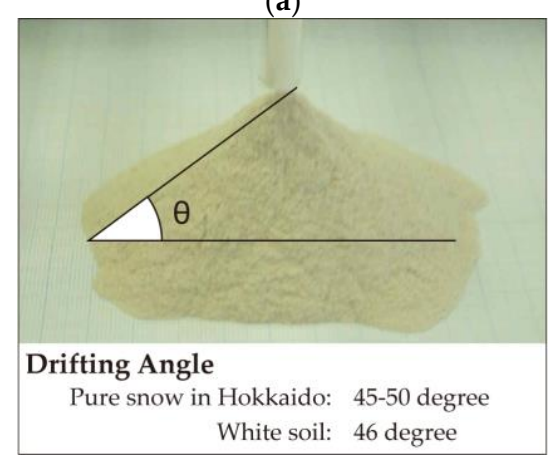

(c)

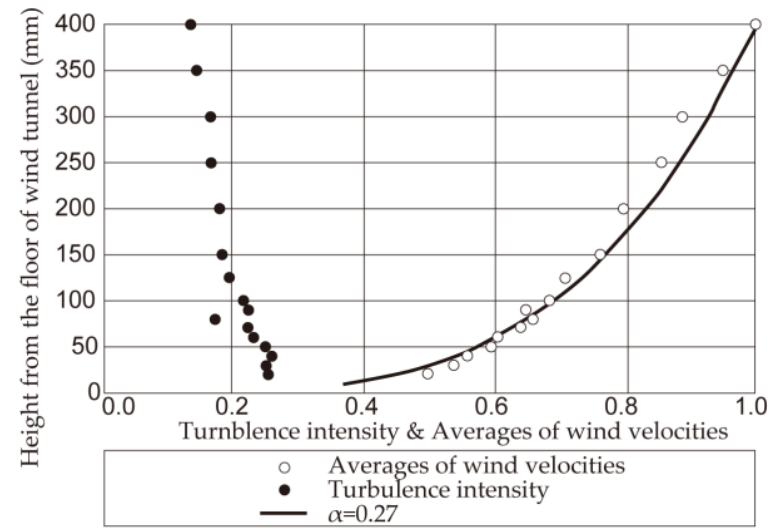

(b)

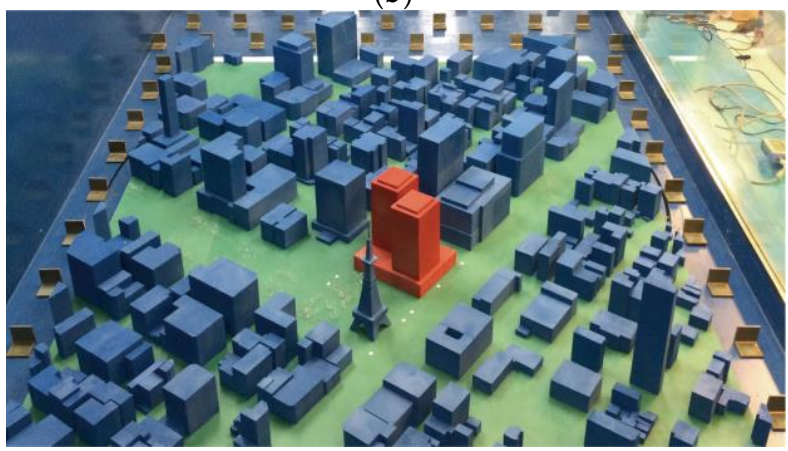

(d)

Figure 2. Snow simulation settings. (a) Wind tunnel; (b) Wind flow in experiments; (c) Activated clay (Snow model); (d) Simulation model.

Previous research reported the reproducibility of this snow simulation method [22,36-39]. This study also proved successful in simulating snowfall and observed differences in snowdrift among the model building designs, using video and the wind simulation tests described below.

In Sapporo, a snowfall of $20 \mathrm{~cm}$ over $12 \mathrm{~h}$ triggers a heavy snowstorm warning; therefore, in this study's snow simulation tests, snowdrifts over $20 \mathrm{~cm}$ were considered to be problematic for pedestrians and traffic.

\subsection{Wind Simulation}

Wind simulation tests were performed in the HRO's boundary-layer wind tunnel. For each wind experiment, a total of 98 measurements were made on the street, on the sidewalk, and in open spaces. A thermistor anemometer (Climomaster model 6542 Kanomax, Osaka, Japan) was used to measure the wind speed. The anemometer stopped for $30 \mathrm{~s}$ at each sampling point in order to gather data at a height of $3 \mathrm{~mm}$. The 30-s sampling time was adopted so that a stable average scalar value of the wind velocity could be obtained at each measurement point [40]. 


\subsection{Building Models}

For the snow and wind simulation tests, the target block building models were manufactured from Styrofoam at a 1:500 scale (Figure 2d). At a real-world scale, the model area would be $912.5 \mathrm{~m}$ in the northwest-southeast direction and $745 \mathrm{~m}$ in the northeast-southwest direction. The simulation times and results were proportional to the model's 1:500 scale; this was achieved using the theory of homothetic ratios for model experiments [41].

\subsection{Snow Removal Energy Consumption}

Using the results from the snow simulations, we estimated the amount of energy required for snow removal along with the resultant $\mathrm{CO}_{2}$ emissions in the target area. The method used for this estimation was based on previous research [32]. Setoguchi et al. [32] estimated the amount of energy required for snow removal using the simulation result in the urban block with medium-density buildings. They divided the amount of snow into covering on the street and the sidewalks, calculated the energy required for transporting the snow on the street and melting the snow on the sidewalks, and estimated the snow removal energy. Table 2 lists the preconditions based on [32], while Table 3 summarizes the estimation process.

Table 2. Preconditions for snow removal energy and emissions estimations.

\begin{tabular}{|c|c|c|}
\hline Basic Information & & \\
\hline Natural snowmelt ${ }^{1}$ & 3.76 & $\mathrm{~cm} /$ day \\
\hline Density of snow in Sapporo ${ }^{2}$ & 393.9 & $\mathrm{~kg} / \mathrm{m}^{3}$ \\
\hline Fusion heat of snow ${ }^{3}$ & 333 & $\mathrm{MJ} / \mathrm{t}$ \\
\hline \multicolumn{3}{|l|}{ Transporting the snow covering the streets } \\
\hline Amount of snow per truckload & 10 & $\mathrm{~T}$ \\
\hline Distance from target area to snow dump and back & 10 & $\mathrm{~km}$ \\
\hline Fuel consumption by one truck (gas oil) ${ }^{4}$ & 2.5 & $\mathrm{~km} / \mathrm{L}$ \\
\hline Caloric value for gas oil ${ }^{5}$ & 37.7 & $\mathrm{MJ} / \mathrm{L}$ \\
\hline $\mathrm{CO}_{2}$ emissions of gas oil ${ }^{5}$ & 2.58 & $\mathrm{kgCO}_{2} / \mathrm{L}$ \\
\hline \multicolumn{3}{|l|}{ Road heating for the snow covering the sidewalks } \\
\hline Efficiency of road heating & 20 & $\%$ \\
\hline Caloric value for heating oil ${ }^{5}$ & 36.7 & $\mathrm{MJ} / \mathrm{L}$ \\
\hline $\mathrm{CO}_{2}$ emissions of heating oil ${ }^{5}$ & 2.49 & $\mathrm{kgCO}_{2} / \mathrm{L}$ \\
\hline
\end{tabular}

\footnotetext{
${ }^{1}$ Japan Meteorological Agency (2009-2014). ${ }^{2}$ Hokkaido Northern Regional Building Research Institute, Study on snow disposal planning of detached house, No. 205, RESEARCH REPORT 2007.3. ${ }^{3}$ Chronological Scientific Tables. ${ }^{4}$ Referred the actual value measured by Japan Institute of Logistics Systems. ${ }^{5}$ The list of calculation methods and emission coefficients in the compulsory system of calculation, report and publishment about greenhouse gases, Ministry of Environment, Government of Japan.
}

Table 3. Estimation process of the snow removal energy.

\begin{tabular}{lcl}
\hline Estimated Items & & Calculation Method \\
\hline 1) Snow cover amount on the streets & $\left(\mathrm{m}^{3} /\right.$ day $)$ & $\mathrm{S}_{\mathrm{t}}$ \\
2) Weight of snow on the streets & $(\mathrm{t} /$ day $)$ & $\mathrm{S}_{\mathrm{t}} \times 393.9 \times 10^{-3}$ \\
3) Number of truckloads of snow & $\mathrm{Ceil}\left(\mathrm{S}_{\mathrm{t}} \times 393.9 \times 10^{-3} \times 1 / 10\right)$ \\
4) Total distance the snow is hauled & $(\mathrm{km} /$ day $)$ & $\mathrm{Ceil}\left(\mathrm{S}_{\mathrm{t}} \times 393.9 \times 10^{-3} \times 1 / 10\right) \times 10$ \\
5) Gas oil volume required for snow hauling & $(\mathrm{L} /$ day $)$ & $\mathrm{Ceil}\left(\mathrm{S}_{\mathrm{t}} \times 393.9 \times 10^{-3} \times 1 / 10\right) \times 10 / 2.5$ \\
6) Required energy to transport the snow & $(\mathrm{GJ} /$ day $)$ & $\mathrm{Ceil}\left(\mathrm{S}_{\mathrm{t}} \times 393.9 \times 10^{-3} \times 1 / 10\right) \times 10 / 2.5 \times 37.7 \times 10^{-3}$ \\
7) $\mathrm{CO}_{2}$ emissions to transport the snow & $\left(\mathrm{tCO}_{2} /\right.$ day $)$ & $\mathrm{Ceil}\left(\mathrm{S}_{\mathrm{t}} \times 393.9 \times 10^{-3} \times 1 / 10\right) \times 10 / 2.5 \times 2.58 \times 10^{-3}$ \\
\hline 8) Snow cover amount on the sidewalks and open spaces & $\left(\mathrm{m}^{3} /\right.$ day $)$ & $\mathrm{S}_{\mathrm{m}}$ \\
9) Weight of snow on the sidewalks and open spaces & $(\mathrm{t} /$ day $)$ & $\mathrm{S}_{\mathrm{m}} \times 393.9 \times 10^{-3}$ \\
10) Heat required to melt the snow & $(\mathrm{GJ} /$ day $)$ & $\mathrm{S}_{\mathrm{m}} \times 393.9 \times 10^{-3} \times 333 \times 10^{-3}$ \\
11) Required energy to melt the snow & $(\mathrm{GJ} /$ day $)$ & $\mathrm{S}_{\mathrm{m}} \times 393.9 \times 10^{-3} \times 333 \times 10^{-3} \times 1 / 0.2$ \\
12) Heating oil volume required for snow melting & $(\mathrm{L} /$ day $)$ & $\mathrm{S}_{\mathrm{m}} \times 393.9 \times 10^{-3} .333 \times 10^{-3} \times 1 / 0.2 \times 36.7 \times 10^{-3}$ \\
13) $\mathrm{CO}_{2}$ emissions to melt the snow & $\left(\mathrm{tCO}_{2} /\right.$ day $)$ & $\mathrm{S}_{\mathrm{m}} \times 393.9 \times 10^{-3} .333 \times 10^{-3} \times 1 / 0.2 \times 36.7 \times 10^{-3}$ \\
& & $\times 2.49 \times 10^{-3}$ \\
\hline 14) Total required energy for snow removal & $(\mathrm{GJ} /$ day $)$ & Result of Equation 6$)+$ Resut of Equation 11$)$ \\
15) Total $\mathrm{CO}_{2}$ emissions from snow removal & $\left(\mathrm{tCO}_{2} /\right.$ day $)$ & Result of Equation $)+$ Result of Equation 13$)$ \\
\hline
\end{tabular}


The amount of snow to be removed from the target area was determined using the snow simulation results. At each measurement point in the simulations, $3.76-\mathrm{cm}$ snow was subtracted from the simulated snow depth to account for natural snowmelt, providing the actual amount of snow to be removed. The amount of snow to be removed from the entire target area, street, sidewalks, and open spaces was calculated as the total amount of snow to be removed at each measurement point (1 and 8 in Table 3$)$.

Two methods are generally used for snow removal: transportation and melting. In this study, we assumed that the snow on the streets was transported out of the target area, while the snow on the sidewalks and open spaces melted. This assumption was based on the current snow removal procedures in Sapporo.

(1) Transportation: The weight of the snow was calculated using the amount of snow in the street and the density of snow in Sapporo $\left(393.9 \mathrm{~kg} / \mathrm{m}^{3} ; 2\right.$ in Table 3). By assuming that the snow was hauled by $10 \mathrm{t}$ trucks, the number of truckloads required could be calculated using the weight of the snow ( 3 in Table 3). A trip to the target area and the nearest snow-piling space and back to the target area was of $10.0 \mathrm{~km}$. The fuel consumed by one truck using gas oil is $2.5 \mathrm{~km} / \mathrm{L}$, and the caloric value of gas oil is $37.7 \mathrm{MJ} / \mathrm{t}$. The amount of $\mathrm{CO}_{2}$ emitted in order to transport the snow was calculated using the $\mathrm{CO}_{2}$ emission rate of gas oil $\left(2.58 \mathrm{kgCO}_{2} / \mathrm{L}\right)$. The above estimation method showed the required energy and $\mathrm{CO}_{2}$ emissions to transport the snow ( 6 and 7 in Table 3).

(2) Melting: The weight of the snow was calculated using the amounts of snow on the sidewalks and in the open spaces along with the density of the snow in Sapporo (9 in Table 3). The energy required to melt the snow was calculated using the weight of the snow, the fusion heat of snow (333 MJ/L), the efficiency of the heating of a road $(20 \%)$, the caloric value of the heating oil $(36.7 \mathrm{MJ} / \mathrm{L})$, and the amount of $\mathrm{CO}_{2}$ emitted by the heating oil $\left(2.58 \mathrm{kgCO}_{2} / \mathrm{L}\right)$. The above estimation indicated the required energy and $\mathrm{CO}_{2}$ emissions to melt the snow (11 and 13 in Table 3).

By summing the estimated results for the transportation and melting of the snow, we obtain the total snow removal energy (14 and 15 in Table 3).

\section{Downtown Sapporo Case Study}

Using a high-density block in downtown Sapporo, Hokkaido Japan, as a case study, this paper developed the desirable urban block design concepts in downtown Sapporo based on the sustainable urban design approach proposed in chapter 2.1 in order to verify the effectiveness of the new approach.

\subsection{Winter Climate in Sapporo}

The Hokkaido region, which is in northern Japan, experiences cold temperatures and heavy snowfall in winter (Figure 3b), and numerous cities and towns in this region face severe snow-related challenges. Figure 3a shows a comparison of the average depth of snow cover from December 2010 to February 2014 for cities located at a latitude of $40^{\circ} \mathrm{N}$ or higher and with populations over 1.5 million. Sapporo, which is located in the Hokkaido region, has one of the heaviest average annual snowfalls in the world [42-45]. Figure 3c depicts the typical winter conditions in Sapporo. Improved urban designs that could alleviate the snow-related challenges that this city faces are a necessity.

Figure 4a shows the total of amount winter snow in Sapporo. The ground is covered with snow for approximately five months in a year. The snow cover reached a depth of $113 \mathrm{~cm}$ on February 22, 2014. Figure $4 \mathrm{~b}$ shows the wind data in Sapporo for winter; we can see that the wind blows strongly from the northwest, often bringing snow with it [46]. 


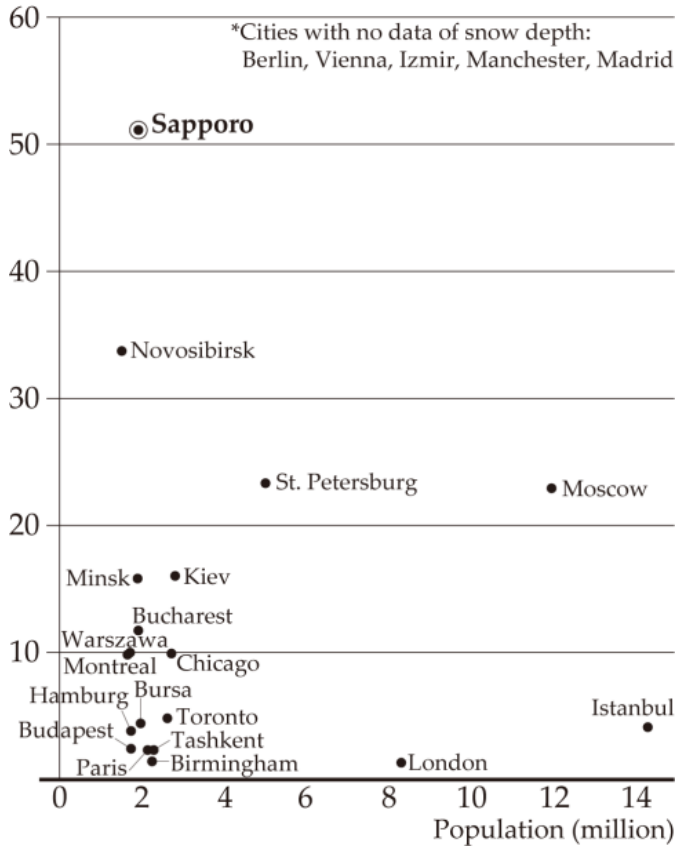

(a)

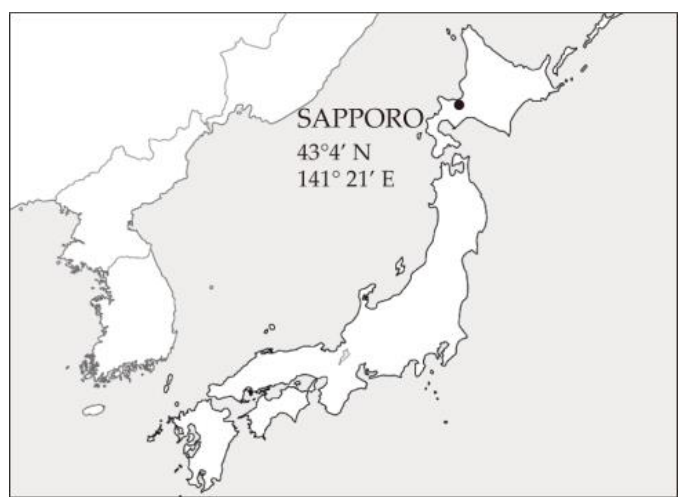

(b)

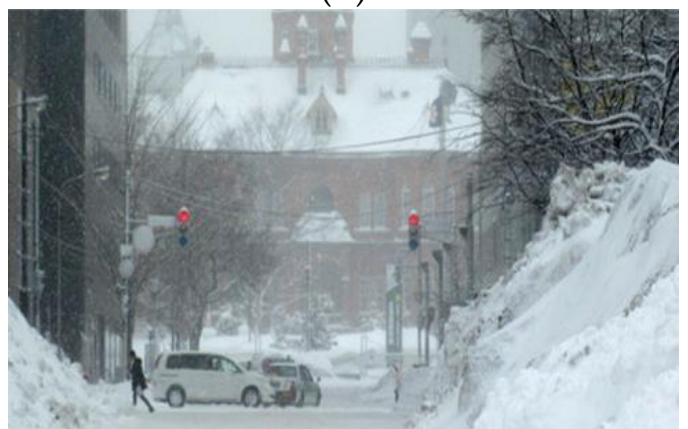

(c)

Figure 3. Information on the weather conditions in Sapporo in winter (a) Average snow cover depth (cm) (December-February/2010-2014); Source of the Population Data: Demographic Yearbook 2013 [42]; Sources of the Climate Data: NNDC Climate Data Online [43]; Weather Online Ltd.-Meteorological Services [44]; Weatherbase [45] (b) Location of Sapporo; (c) Former Hokkaido Government Office in downtown Sapporo in Winter.

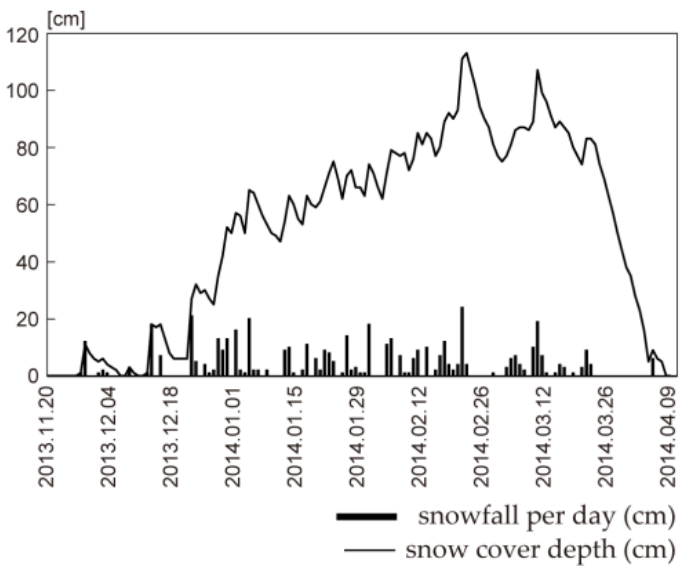

(a)

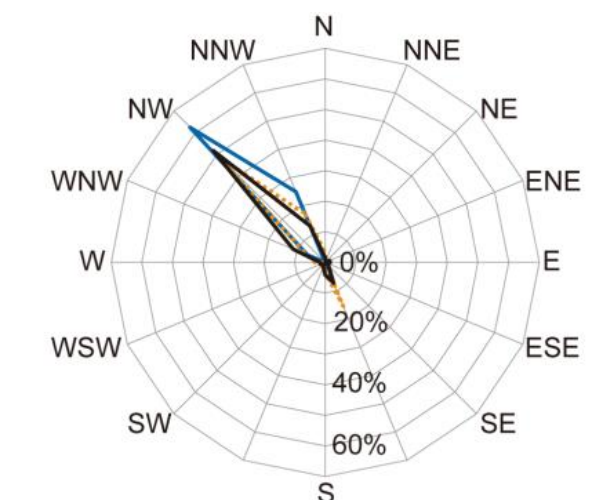

- Over $5 \mathrm{~cm}$ - Over $20 \mathrm{~cm} \quad \cdots . .$. Over $5 \mathrm{~m} / \mathrm{s}$

Figure 4. Snow and wind data in downtown Sapporo. (a) Snow cover data for Sapporo; Source of the Data: Japan Meteorological Agency, Past weather data [46] (b) Wind rose for Sapporo. Source of the Data: Japan Meteorological Agency, Past weather data [46] 


\subsection{Target Simulation Area}

The Odori district, which is a business and commercial center in downtown Sapporo, was originally designated as an urban core area in the Sapporo Urban Community Development Plan 2011 [47]. The target block considered in this study is located in this district. Figure $5 a, b$ shows the location of the target block (dark shaded area). The target block faces Odori Park and Sosei River Street, and many pedestrians pass through it in the winter. A redevelopment project is currently underway north of the target block, and the target block will possibly be redeveloped in the near future.

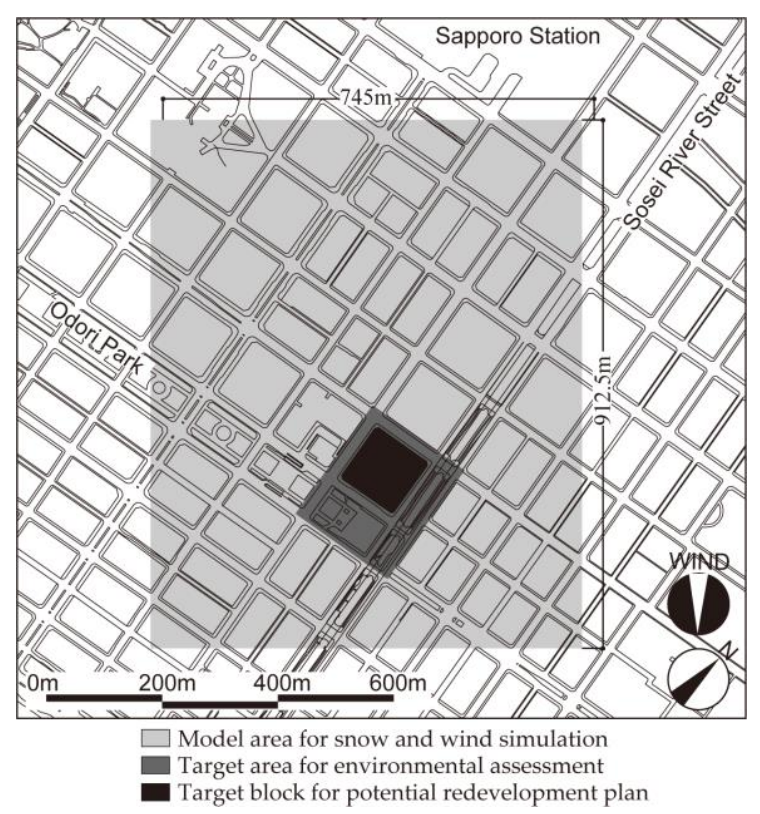

(a)

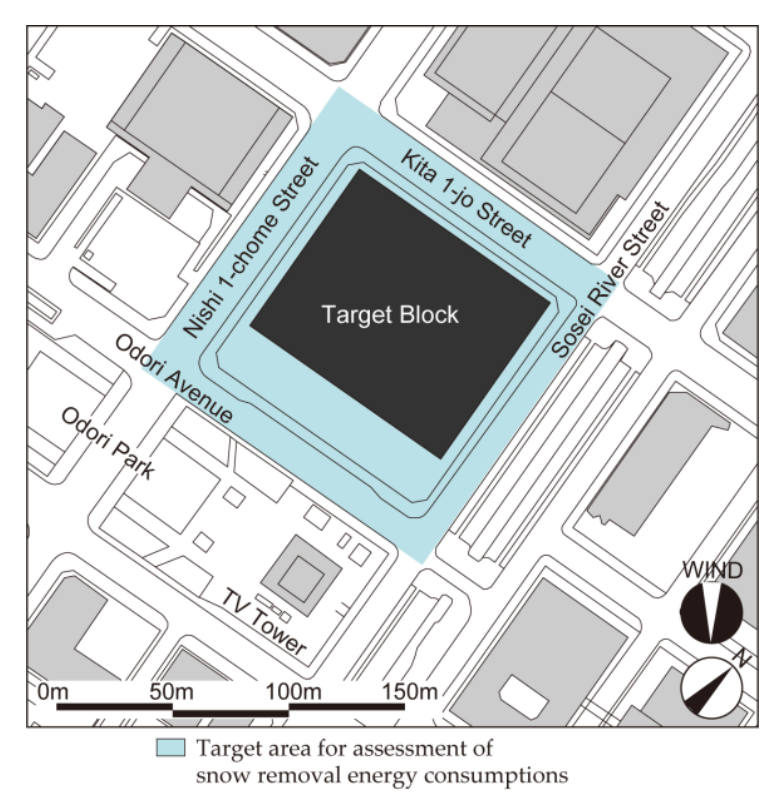

(b)

Figure 5. Target area and block in downtown Sapporo. (a) Model area for snow and wind simulation; (b) Target block and target area for the assessment.

\subsection{Analysis of the High-Rise and High-Density Urban Block Designs in Downtown Sapporo}

Figure 6 shows the urban blocks with high-rise buildings (the building heights are over $60 \mathrm{~m}$ ) and high-density (the total FARs in each block are over 600\%) in downtown Sapporo. The building heights in the urban blocks are classified into three groups [high-rise (over $60 \mathrm{~m}$ ), mid-rise (45-60 m) and low-rise (under $45 \mathrm{~m}$ )] based on the boundaries of height in Japanese Building Standard Act. Analyzing the shapes of the urban blocks, there are the following three characteristics; (1) The high-rise buildings are built with low-rise parts (podiums). (2) The building height ratios (BHR; the ratio of the maximum building height to the average building height in the urban block) are classified into two groups [group A (BHR is more than 2.0) and group B (BHR is under 2.0)]. (3) The compositions of the high-rise structures (other than the low-rise parts and buildings) are classified into two groups [group 1 (high-rise and mid-rise parts) and group 2 (only high-rise parts)]. 


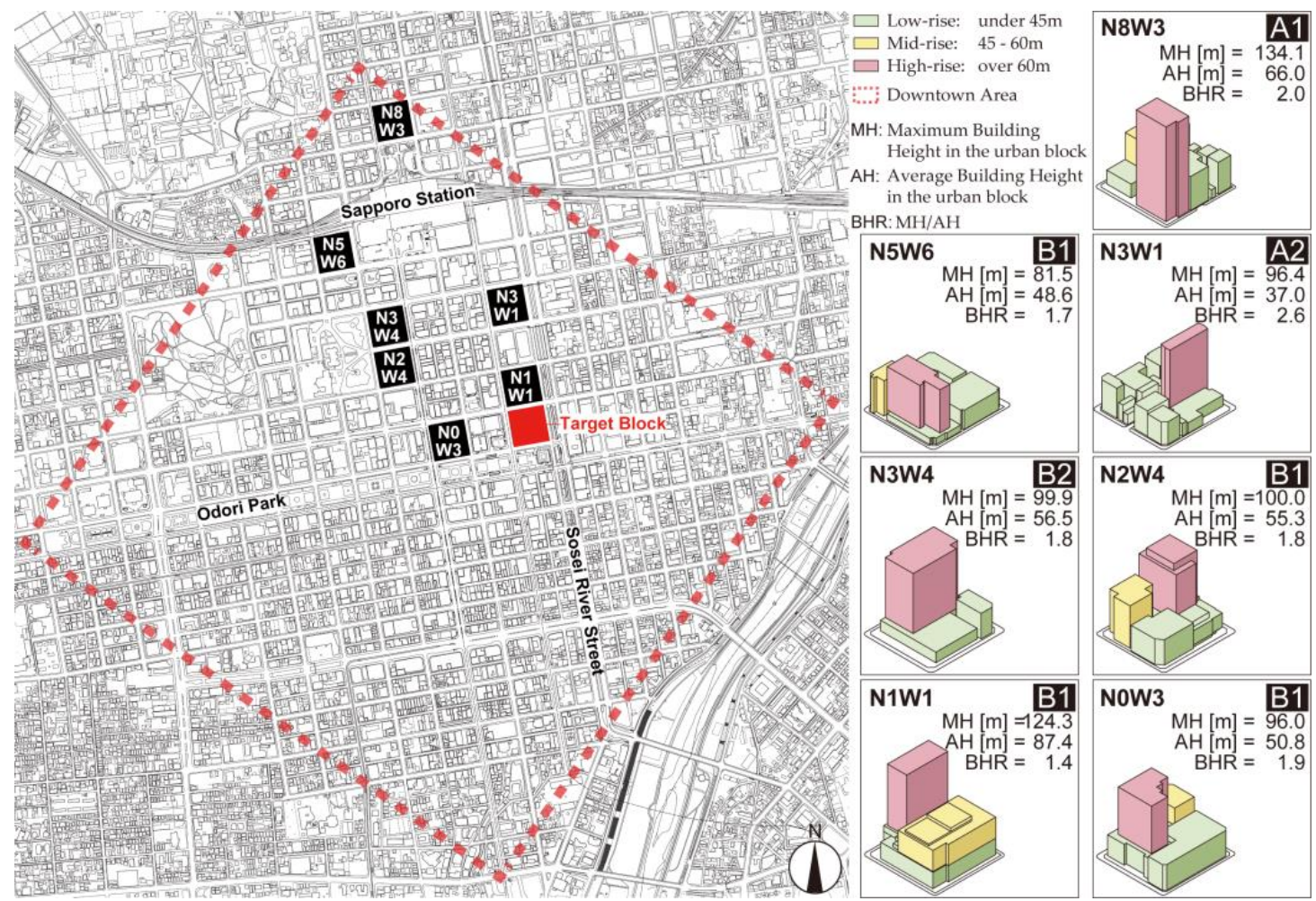

Figure 6. High-rise and high-density urban blocks in downtown Sapporo.

Based on the three characteristics, the high-rise and high-density urban blocks in downtown Sapporo are classified into the four types of urban block designs (A1, A2, B1 and B2 in Figures 6 and 7 ). The urban block design models that were planned based on the four types of urban block designs are shown in Figure 8. The FAR of all models were assumed to be $1000 \%$ to reflect the recent developments in the downtown area. All models had the same shaped podiums.
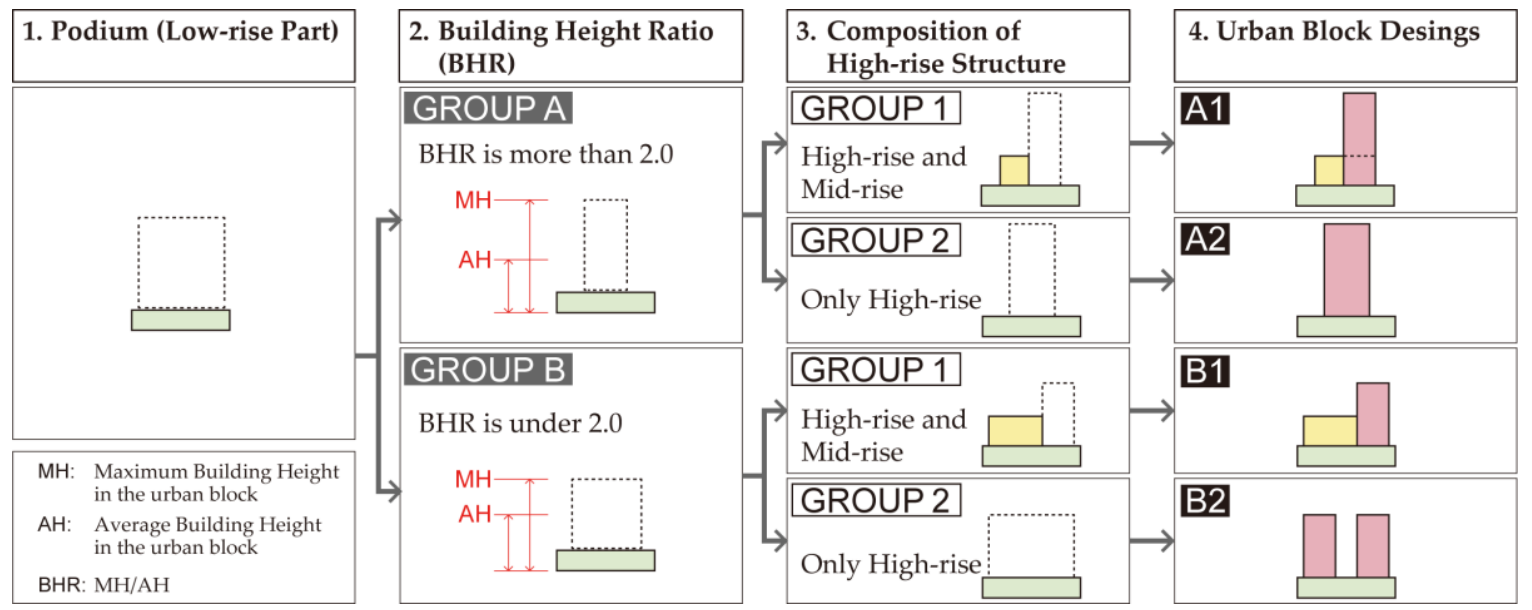

Figure 7. Typology of the urban block designs in downtown Sapporo. 


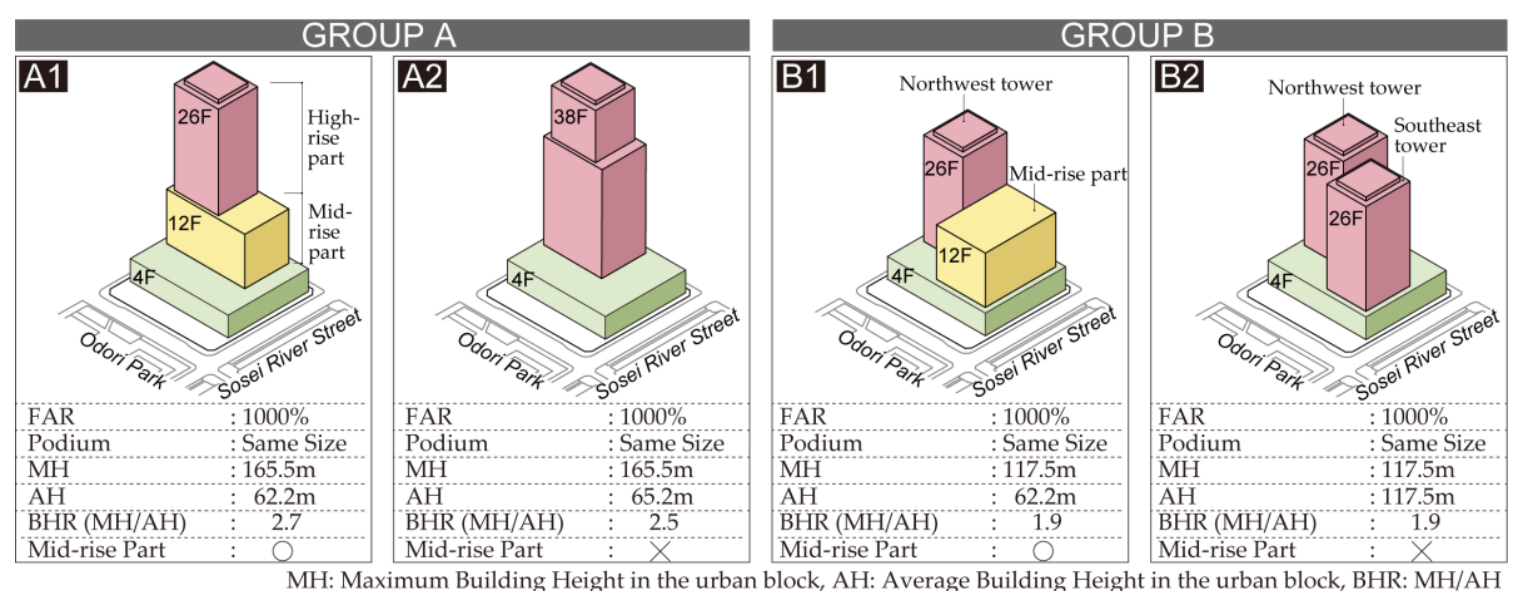

Figure 8. High-rise and high-density urban blocks in downtown Sapporo.

\subsection{Process for Evaluating the Urban Block Designs}

Figure 9 shows the process for evaluating the urban block design models. The four urban block design models are tested using snow and wind simulations in a wind tunnel. The models are evaluated using the results of the snowy and windy conditions as well as the energy required for snow removal. The evaluation has the following five steps in chapter 4:

1) Analyzing the common points in the group A (Case A1 and A2).

2) Analyzing the common points in the group B (Case B1 and B2).

3) Analyzing the differences between the group A and B to clarify the effect of the building height ratios.

4) Analyzing the differences between the case A1 and A2 to clarify the effects of the mid-rise parts in the group A.

5) Analyzing the differences between the case B1 and B2 to clarify the effects of the mid-rise parts in the group B.

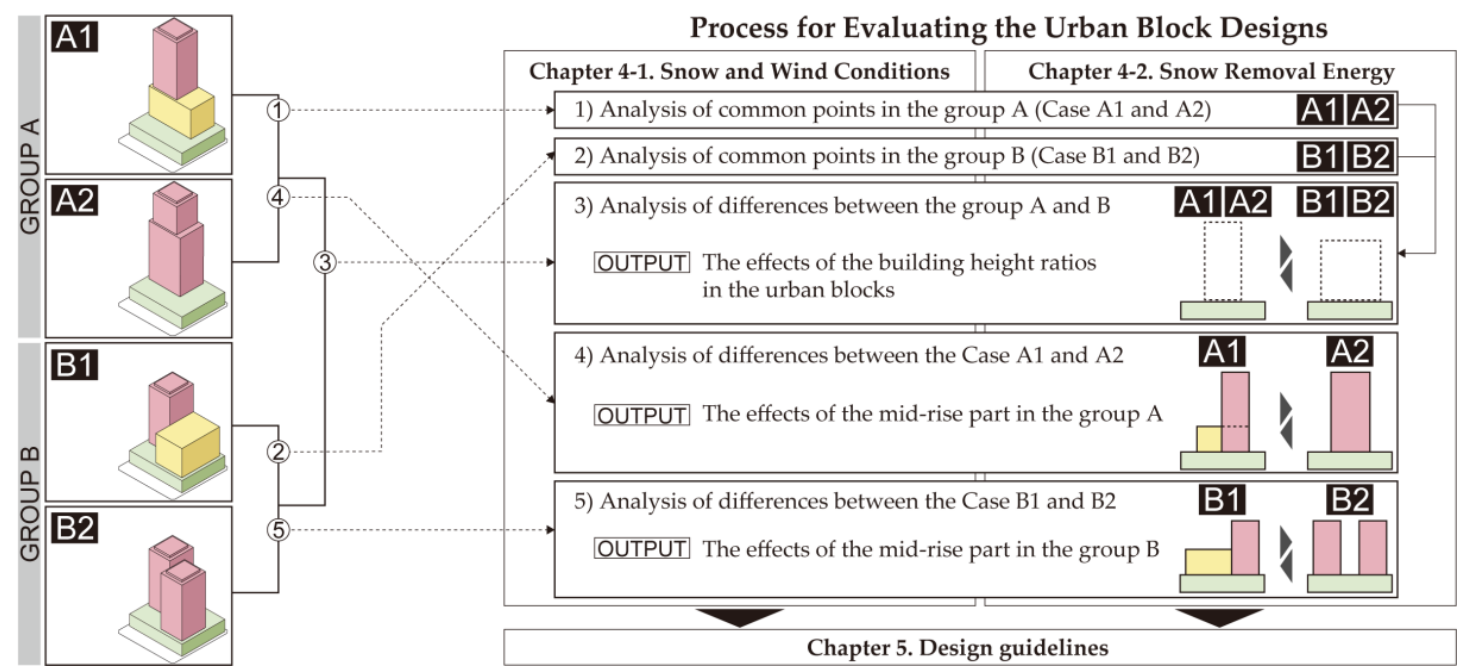

Figure 9. Process for evaluating the urban block designs. 


\section{Results and Discussion}

\subsection{Snow and Wind Conditions}

The four urban block models were tested using snow and wind simulations in wind tunnels. The results of the simulations are shown in Figures 10-13.

1) The common points in group A: Snowdrifts were formed on the open space along Odori Park (point A in Figures 10 and 11). There was no snowdrift around the crossing of Sosei River Street and Kita 1-jo Street (point B in Figures 10 and 11). There was no snowdrift on the sidewalk of Sosei River Street (point C in Figures 10 and 11). No snowdrift was observed around the crossing of Sosei River Street and Odori Avenue (point D in Figures 10 and 11). There was a large area around the southeast block wherein no snowdrift formed (point E in Figures 10 and 11).

2) The common points in group B: Snowdrifts were formed on the open space along Odori Park (point A in Figures 10 and 11). The snowdrift depths were almost same, $23.0 \mathrm{~cm}$ and $23.1 \mathrm{~cm}$ in the case B1 and B2 respectively, potentially causing problems for pedestrians. Snowdrifts formed on the sidewalk of Sosei River Street (point C in Figures 12 and 13). Snowdrifts formed around the crossing of Sosei River Street and Odori Avenue and the snowdrift depths were $15.9 \mathrm{~cm}$ and $16.6 \mathrm{~cm}$ in the case B1 and B2 (point D in Figures 12 and 13).

3) The differences between group A and B: There were two differences between the group A and group B. On the sidewalk of Sosei River Street, there was no snowdrifts in the group A, however, a snowdrift formed in group B (point C in Figures 10-13). As the building height was taller in group A, the strong deflected winds produced a larger area with no snowdrifts, which in turn caused no snow to land over a large area. In group B, winds deflected by the northwest tower were intercepted by the southeast tower or the mid-rise part, which reduced the wind velocity on the ground and caused the formation of snowdrifts. In addition, the area of the roof of the podium in group A was larger than that in group B, the snow that could cover the roof was greater, indicating that the design had less snowdrifts.

Around the crossing of Sosei River Street and Odori Avenue, there was no snowdrifts in group A; however, snowdrifts formed in group B (point D in Figures 10-13). As the building height was taller in group A, the strong deflected wind traveled to the ground, which caused it to blow away any snow that was at this location.

4) The differences between the case A1 and A2: The depth of snow covering the open spaces in the case A2 was lower than that in the case A1 $(12.0 \mathrm{~cm}$ as opposed to $26.6 \mathrm{~cm}$; point A in Figures 10 and 11). Because the area of the roof of the podium was increased in the case A2, more snow covered the roof, and therefore, less snow covered the ground.

5) The differences between the case B1 and B2: There were two differences between the case B1 and B2. Snowdrifts formed around the crossing of Sosei River Street and Kita 1-jo Street in the case B1, however, there was no snowdrift in the case B2 (point B in Figures 12 and 13). In the case B1, winds deflected by the northwest tower were intercepted by the mid-rise part, which reduced the wind velocity on the ground and caused the formation of snowdrifts.

There was a small area around the southeast block wherein no snowdrift formed in the case B2 (point E in Figure 13). In contrast, in the case B1, snowdrifts were formed $(21.6 \mathrm{~cm})$ (point E in Figure 12). The wind deflected by the northwest tower produced the no snowdrift area in the case B2. In the case B1, winds deflected by the northwest tower were intercepted by the mid-rise southeast tower, which reduced the wind velocity on the ground and caused the formation of snowdrifts. 


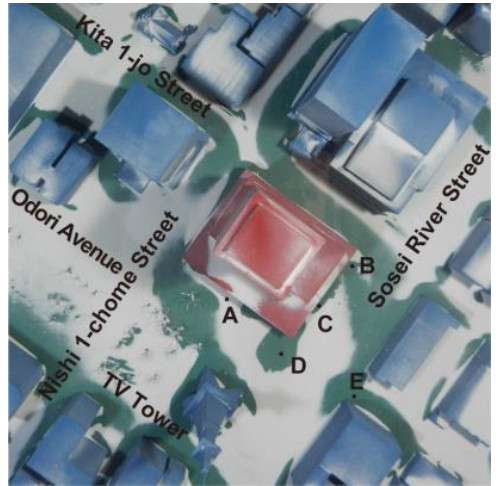

(a)

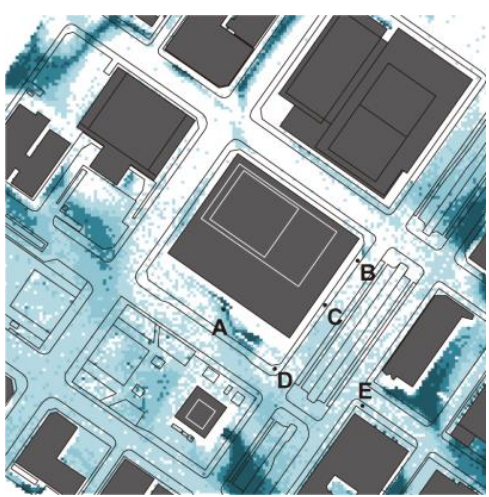

(b)

Snow Depth $\quad \square \sim 49 \mathrm{~mm} \quad \square 50 \mathrm{~mm} \sim 99 \mathrm{~mm} \quad \square 100 \mathrm{~mm} \sim 149 \mathrm{~mm} \quad \square 150 \mathrm{~mm} \sim 199 \mathrm{~mm} \quad \square 200 \mathrm{~mm}$

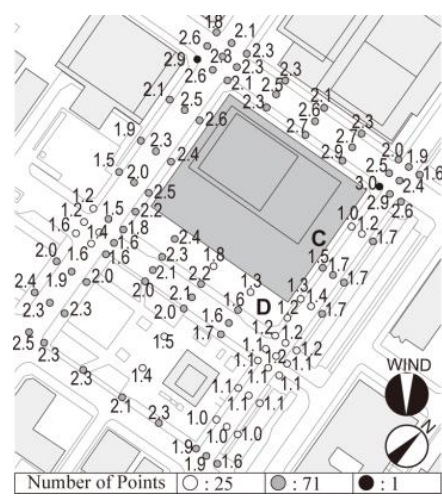

(c)

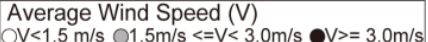

Figure 10. Snow and wind simulation results in Case A1. (a) Snow simulation result; (b) Snow depth; (c) Wind simulation result.

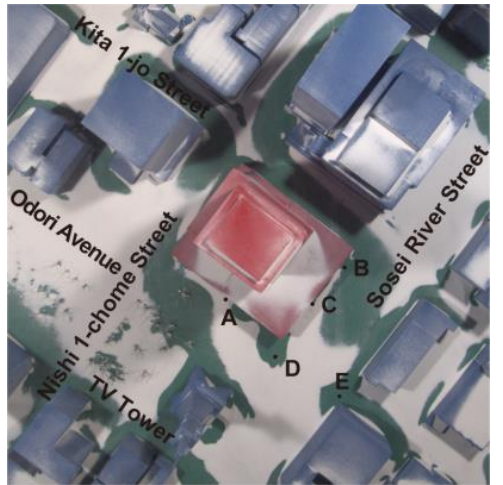

(a)

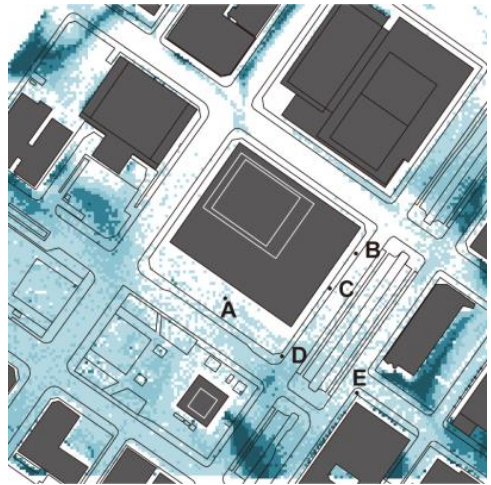

(b)

Snow Depth $\quad \square \sim 49 \mathrm{~mm} \quad \square 50 \mathrm{~mm} \sim 99 \mathrm{~mm} \quad \square 100 \mathrm{~mm} \sim 149 \mathrm{~mm} \quad \square 150 \mathrm{~mm} \sim 199 \mathrm{~mm} \quad \square 200 \mathrm{~mm}$

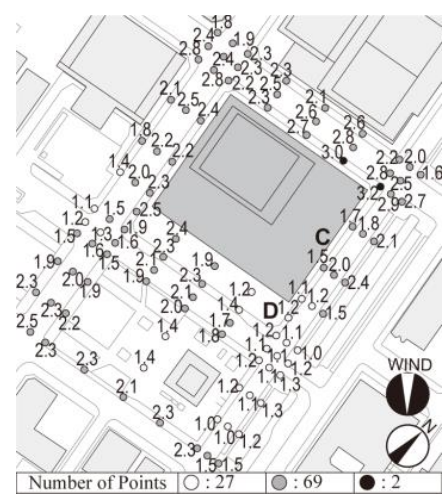

(c)

Average Wind Speed (V)
$\mathrm{OV}<1.5 \mathrm{~m} / \mathrm{s} \quad 01.5 \mathrm{~m} / \mathrm{s}<=\mathrm{V}<3.0 \mathrm{~m} / \mathrm{s} \quad \mathrm{VV}>=3.0 \mathrm{~m} / \mathrm{s}$

Figure 11. Snow and wind simulation results in Case A2. (a) Snow simulation result; (b) Snow depth; (c) Wind simulation result.

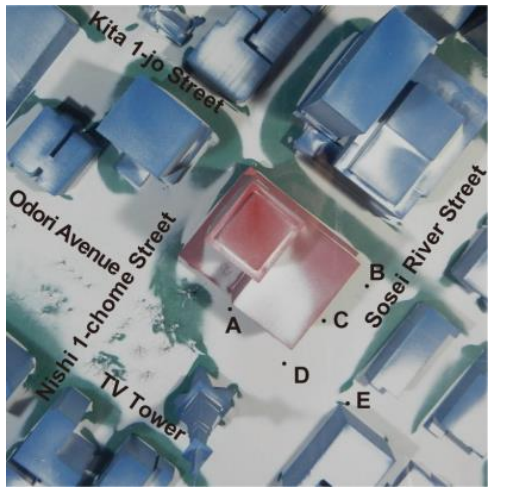

(a)

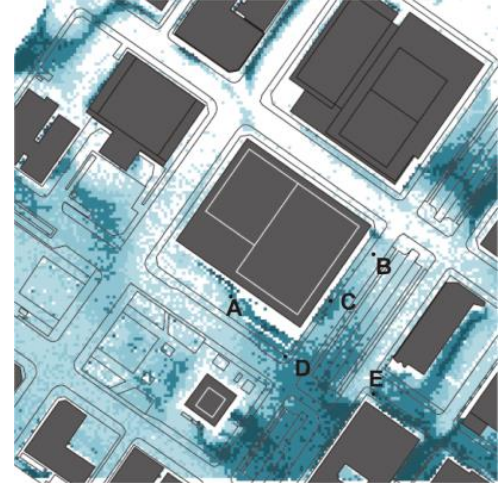

(b)

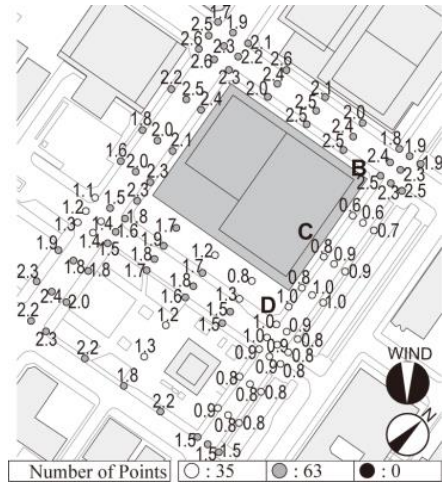

(c)

Snow Depth $\quad \square \sim 49 \mathrm{~mm} \quad \square 50 \mathrm{~mm} \sim 99 \mathrm{~mm} \quad \square 100 \mathrm{~mm} \sim 149 \mathrm{~mm} \quad \square 150 \mathrm{~mm} \sim 199 \mathrm{~mm} \quad \square 200 \mathrm{~mm} \sim$

Average Wind Speed $(\mathrm{V})$
$\mathrm{OV}<1.5 \mathrm{~m} / \mathrm{s} \quad 01.5 \mathrm{~m} / \mathrm{s}<=\mathrm{V}<3.0 \mathrm{~m} / \mathrm{s} \quad \mathrm{V}>=3.0 \mathrm{~m} / \mathrm{s}$

Figure 12. Snow and wind simulation results in Case B1. (a) Snow simulation result; (b) Snow depth; (c) Wind simulation result. 


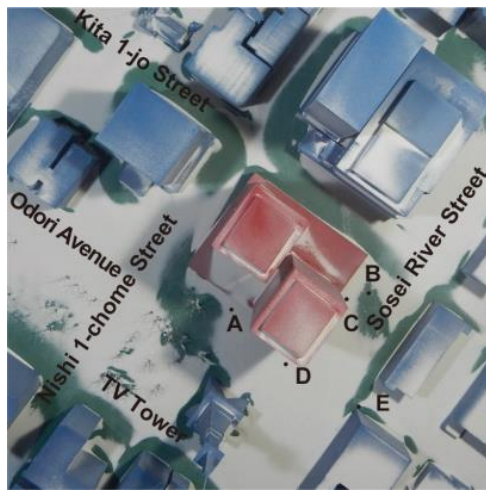

(a)

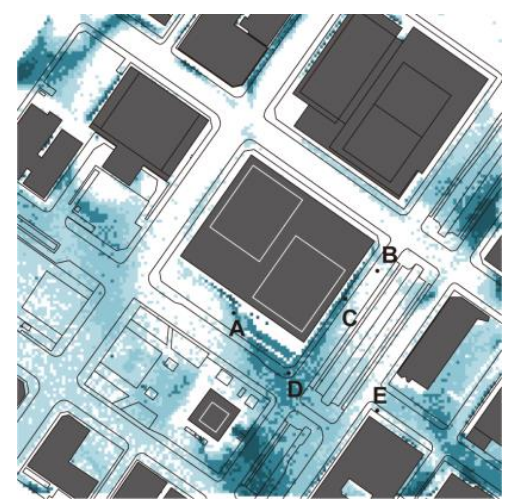

(b)

Snow Depth $\square \sim 49 \mathrm{~mm} \quad \square 50 \mathrm{~mm} \sim 99 \mathrm{~mm} \quad \square 100 \mathrm{~mm} \sim 149 \mathrm{~mm} \quad \square 150 \mathrm{~mm} \sim 199 \mathrm{~mm} \quad \square 200 \mathrm{~mm}$

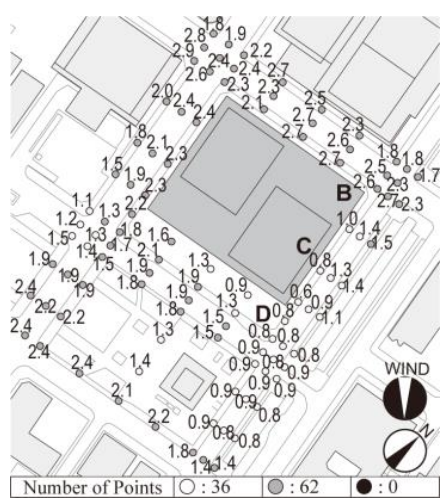

(c)

Average Wind Speed $(\mathrm{V})$

Figure 13. Snow and wind simulation results in Case B2. (a) Snow simulation result; (b) Snow depth; (c) Wind simulation result.

\subsection{Snow Removal Energy}

The amounts of energy required for snow removal along with the resultant $\mathrm{CO}_{2}$ emissions in the four urban block models were estimated using the results from the snow simulations. The results for the estimations are shown in Table 4.

1) The common points in group A: The amount of snow cover was reduced in group A. Group A required small snow removal energy; $76.9 \mathrm{GJ} /$ day for case A1 and $43.1 \mathrm{GJ} /$ day for case A2.

2) The common points in group B: The amount of snow cover was increased in group B. Group B required great snow removal energy; $152.0 \mathrm{GJ} /$ day for case B1 and $130.7 \mathrm{GJ} /$ day for case B2.

3) The differences between group A and B: Group A required less snow removal energy than group B. In group A, the wind deflected from the higher tower produced larger areas with no snowdrifts in them and reduced the amount of snow cover, thereby requiring less snow removal energy.

4) The differences between case A1 and A2: Case A2 required less snow removal energy than case A1. Because the area of the roof of the podium in case A2 was larger than that in case A1, the amount of snow that could cover the roof was greater, indicating that the design had less amounts of snow covering the ground.

5) The differences between case B1 and B2: Case B1 required greater snow removal energy than case B2. In case B1, the wind deflected by the northwest tower was intercepted by the mid-rise part, which reduced the wind velocity on the ground and subsequently increased the snowdrifts, thereby requiring greater snow removal energy.

Table 4. Results for the estimations of the snow removal energy.

\begin{tabular}{lccccc}
\hline Estimated Items & & Case A1 & Case A2 & Case B1 & Case B2 \\
\hline a) Snow cover amount on target area & $\left(\mathrm{m}^{3} /\right.$ day $)$ & 599.6 & 478.0 & 869.0 & 702.6 \\
b) Snow cover amount to be removed from target area & $\left(\mathrm{m}^{3} /\right.$ day $)$ & 220.4 & 150.8 & 462.7 & 369.0 \\
c) Percentage of snow on the streets & $(\%)$ & 51.5 & 62.1 & 55.8 & 50.6 \\
d) Percentage of snow on the sidewalks and open spaces & $(\%)$ & 48.5 & 37.9 & 45.2 & 49.4 \\
\hline 1) Snow cover amount on the streets & $\left(\mathrm{m}^{3} /\right.$ day $)$ & 113.4 & 93.6 & 258.2 & 186.7 \\
2) Weight of snow on the streets & $(\mathrm{t} /$ day $)$ & 44.7 & 36.9 & 101.7 & 73.5 \\
3) Number of truckloads of snow & & 45 & 37 & 102 & 74 \\
4) Total distance the snow is haule & $(\mathrm{km} /$ day $)$ & 450.0 & 370.0 & 1020.0 & 740.0 \\
5) Gas oil volume required for snow hauling & $(\mathrm{L} /$ day $)$ & 180.0 & 148.0 & 408.0 & 296.0 \\
6) Required energy to transport the snow & $(\mathrm{GJ} /$ day $)$ & 6.8 & 5.6 & 15.4 & 11.2 \\
7) $\mathrm{CO}_{2}$ emissions to transport the snow & $\left(\mathrm{tCO}_{2} /\right.$ day $)$ & 0.46 & 0.38 & 1.05 & 0.76 \\
\hline
\end{tabular}


Table 4. Cont.

\begin{tabular}{lccccc}
\hline Estimated Items & & Case A1 & Case A2 & Case B1 & Case B2 \\
\hline 8) Snow cover amount on the sidewalks and open spaces & $\left(\mathrm{m}^{3} /\right.$ day $)$ & 106.9 & 57.2 & 208.3 & 182.3 \\
9) Weight of snow on the sidewalks and open spaces & $(\mathrm{t} /$ day $)$ & 42.1 & 22.5 & 82.0 & 71.8 \\
10) Heat required to melt the snow & $(\mathrm{GJ} /$ day $)$ & 14.0 & 7.5 & 27.3 & 23.9 \\
11) Required energy to melt the snow & $(\mathrm{GJ} /$ day $)$ & 70.1 & 37.5 & 136.6 & 119.6 \\
12) Heating oil volume required for snow melting & $(\mathrm{L} /$ day) & 1911.1 & 1021.3 & 3721.6 & 3258.6 \\
13) $\mathrm{CO}_{2}$ emissions to melt the snow & $\left(\mathrm{tCO}_{2} /\right.$ day $)$ & 4.76 & 2.54 & 9.27 & 8.11 \\
\hline 14) Total required energy for snow removal & $(\mathrm{GJ} /$ day $)$ & 76.9 & 43.1 & 152.0 & 130.7 \\
15) Total $\mathrm{CO}_{2}$ emissions from snow removal & $\left(\mathrm{tCO}_{2} /\right.$ day $)$ & 5.22 & 2.92 & 10.32 & 8.88 \\
\hline
\end{tabular}

\section{Conclusions}

This study considered urban block designs with high-rise and high-density buildings and their effects on the snow and wind conditions in public spaces, energy requirements, and $\mathrm{CO}_{2}$ emissions that would be produced in order to remove snow from a block in the downtown area of Sapporo, Japan. The snow and wind conditions and the snow removal energy of a variety of urban block models were evaluated using wind tunnels. The planning and assessing processes of this study along with guidelines for the most ideal design are summarized in Figure 14. Our advice for the urban block designs that consider the severe winter climate in Sapporo can be summarized as follows:

1) Building Height Ratio (Figure 14b): A higher building height ratio (BHR; the ratio of the maximum building height to the average building height in the urban block) like the group $\mathrm{A}$ is better for the urban block as this improves the snow conditions and lowers the required snow removal energy. Because the tower is taller and the area of the roof of the podium is larger, the wind deflected from the tower to the ground can be increased, which can be used to blow away any snow covering the ground, and the amount of snow that could cover the podium's roof was greater, thereby reducing the formation of snowdrifts and lowering the snow removal energy required.

2) Mid-rise part in group A (Figure 14c): When an urban block is designed with high BHR like the group $\mathrm{A}$, urban block design without the mid-rise part will reduce the formation of snowdrifts on the ground and lower the required snow removal energy. Because the area of the roof of the podium was larger, the snow covering the roof increased, thereby causing less snow to drift onto the ground.

3) Mid-rise part in group B (Figure 14c): When an urban block is designed with low BHR like the group $B$, urban block design with the mid-rise part will increase the formation of snowdrifts on the ground and raise the required snow removal energy. Because the area of the roof of the podium is smaller, the snow covering the roof decreased, thereby causing more snow to drift onto the ground. In addition, the winds deflected by the high-rise tower were intercepted by the mid-rise part, which reduced the wind velocity on the ground and caused the formation of snowdrifts.

This study proposed the sustainable urban design approach for winter cities integrating environmental and energy assessments for snow and wind conditions into the designs (chapter 2.1). The findings suggested ideal urban block design concepts for high-rise and high-density districts in Sapporo. The design concepts are applicable in downtown Sapporo; however, the proposed sustainable urban design approach would be effective in improving public-space environments and reducing the required snow removal energy in other winter cities. This approach should be considered as it has the potential to enhance sustainable urban designs in winter cities. 
a) Podium

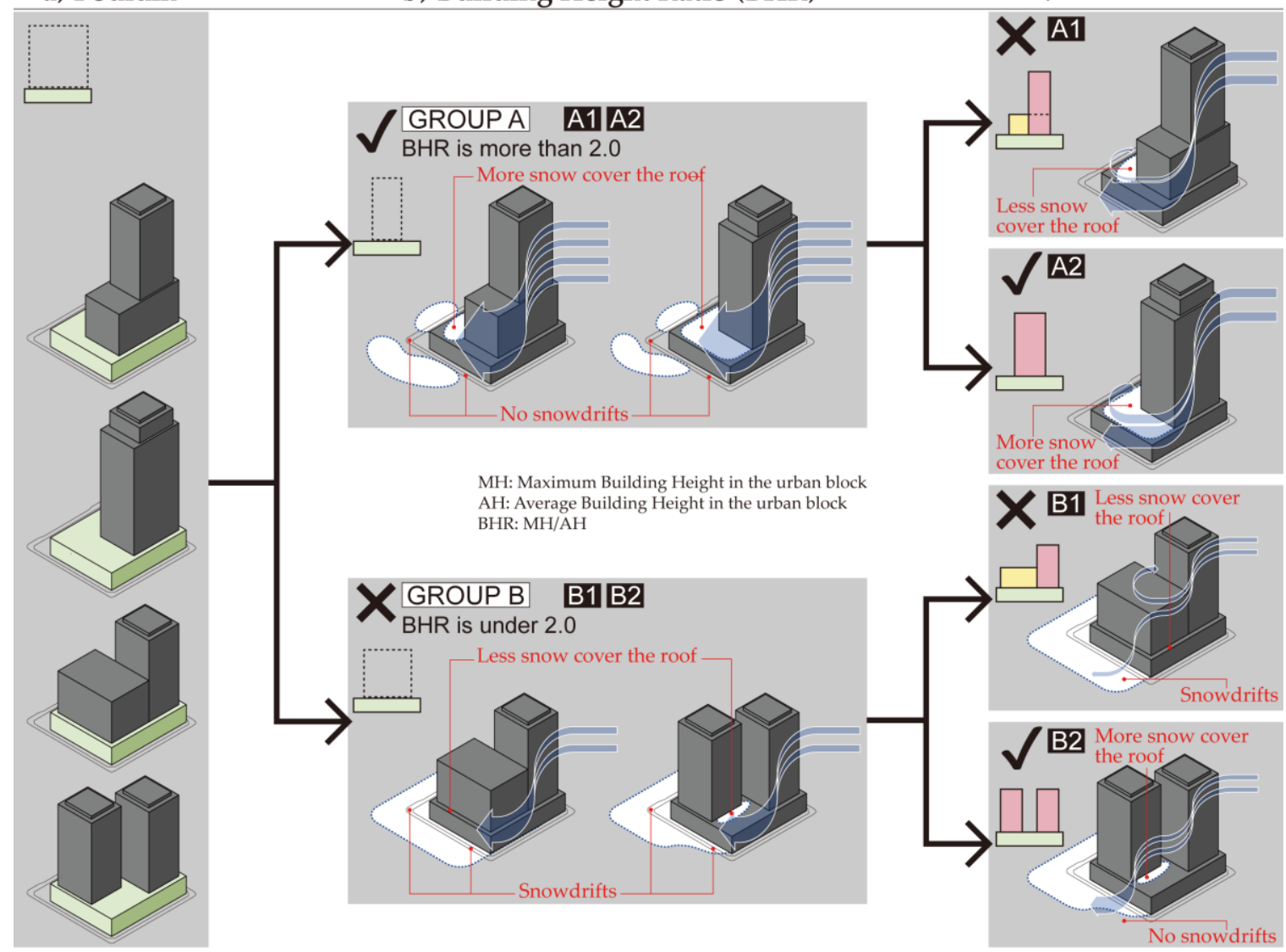

Figure 14. The study process and design guidelines.

This study used one urban block as a case study and determined the effect of various urban block designs on both the snow and wind conditions in various blocks as well as the amount of energy required for snow removal in Sapporo. It remains a challenge for future research to consider the environmental and energy assessments in designs of multiple urban blocks. Future related research also should consider additional types of urban block designs in other winter cities. Additional studies would improve understanding of and lead to potential environmental and energy benefits in winter cities attributable to improved urban block designs.

Acknowledgments: This work was supported by JSPS KAKENHI Grant Number 25249082.

Author Contributions: Norihiro Watanabe conducted the case study, performed the experiments, analyzed the data, and wrote the paper; Tsuyoshi Setoguchi guided this study, developed the research framework, and revised the manuscript; Kosuke Maeda and Daiki Iwakuni performed the experiments and analyzed the data; Zhiming Guo analyzed the data and revised the manuscript; Takuya Tsutsumi performed the experiments, guided the data analysis and revised the manuscript.

Conflicts of Interest: The authors declare no conflict of interest.

\section{References}

1. Hebbert, M.; Jankovic, V. Cities and Climate Change: The Precedents and Why They Matter. Urban Stud. 2013, 50, 1332-1347. [CrossRef]

2. Juan, S.; Yoon, S. Deduction of Optimum Surface Design Factors for Enhancement of Outdoor Thermal Environment in a Micro-Scale Unit. Sustainability 2017, 9, 1381. [CrossRef]

3. Heidari, A.; Sahebzadeh, S.; Dalvand, Z. Natural Ventilation in Vernacular Architecture of Sistan, Iran; Classification and CFD Study of Compound Rooms. Sustainability 2017, 9, 1048. [CrossRef] 
4. Yuan, C.; Ng, E. Building porosity for better urban ventilation in high-density cities-A computational parametric study. Build. Environ. 2012, 50, 176-189. [CrossRef]

5. Yuan, C.; Ng, E. Practical application of CFD on environmentally sensitive architectural design at high density cities: A case study in Hong Kong. Urban Clim. 2014, 8, 57-77. [CrossRef]

6. $\mathrm{Ng}$, E. Policies and technical guidelines for urban planning of high-density cities-Air ventilation assessment (AVA) of Hong Kong. Build. Environ. 2009, 44, 1478-1488. [CrossRef]

7. Ng, E.; Yuan, C.; Chen, L.; Ren, C.; Fung, J.C. Improving the wind environment in high-density cities by understanding urban morphology and surface roughness: A study in Hong Kong. Landsc. Urban Plan. 2011, 101, 59-74. [CrossRef]

8. Szúcs, Á. Wind comfort in a public urban space-Case study within Dublin Docklands. Front. Arch. Res. 2013, 2, 50-66. [CrossRef]

9. Blocken, B.; Janssen, W.D.; Hoff, T.V. CFD simulation for pedestrian wind comfort and wind safety in urban areas: General decision framework and case study for the Eindhoven University campus. Environ. Model. Softw. 2012, 30, 15-34. [CrossRef]

10. Capeluto, I.G.; Yezioro, A.; Shaviv, E. Climatic aspects in urban design-A case study. Build. Environ. 2003, 38, 827-835. [CrossRef]

11. Pressman, N. Northern Cityscape: Linking Design to Climate, 1st ed.; Enai, M., Ed.; Hokkaido University Press: Sapporo, Japan, 2002; pp. 49-143.

12. Ebrahimabadi, S.; Nilsson, K.L.; Johansson, C. The problems of addressing microclimate factors in urban planning of the subarctic regions. Environ. Plan. B Urban Anal. City Sci. 2015, 42, 415-430. [CrossRef]

13. Tominaga, Y.; Okaze, T.; Mochida, A. CFD modeling of snowdrift around a building: An overview of models and evaluation of a new approach. Build. Environ. 2011, 46, 899-910. [CrossRef]

14. Okaze, T.; Tominaga, Y.; Mochida, A. Development of new snowdrift model based on two transport equations of drifting snow density: Numerical prediction of snowdrift around building using CFD (Part 2). J. Environ. Eng. 2013, 78, 149-156. [CrossRef]

15. Kim, H.; Macdonald, E. Wind and the city: An evaluation of San Francisco's planning approach since 1985. Environ. Plan. B Urban Anal. City Sci. 2015, 44, 10-32. [CrossRef]

16. Murota, T. Wind tunnel modeling for flow around buildings. J. Wind Eng. 1984, 20, 33-49. [CrossRef]

17. Kobayashi, T.; Chikamoto, T.; Umemiya, N.; Osada, K. Estimation of Natural Ventilation Flow Rate for a Pitched-Roof Detached House Provided with Monitor Roof. J. Environ. Eng. 2016, 81, 83-91. [CrossRef]

18. Ishizaki, H.; Sung, I.; Kumatoi, T. Wind Tunnel Experiments of a Suspended Roof. Trans. Arch. Inst. Jpn. 1966, 126, 9-13. [CrossRef]

19. Meng, X.; Setoguchi, T. Development of Urban Design Guidelines with Wind Tunnel Simulations for Downtown Districts in Winter Cities. J. Asian Arch. Build. Eng. 2010, 9, 355-362. [CrossRef]

20. Bosselmann, P.; Flores, J.; Gray, W.; Priestley, T.; Anderson, R.; Arens, E.; Dowty, P.; So, S.; Kim, J.J. Sun, Wind, and Comfort: A Study of Open Spaces and Sidewalks in Four Downtown Areas; Institute of Urban \& Regional Development, College of Environmental Design, University of California: Berkeley, CA, USA, 1984.

21. Arens, E.; Bosselmann, P. Wind, sun and temperature-Predicting the thermal comfort of people in outdoor spaces. Build. Environ. 1989, 24, 315-320. [CrossRef]

22. Anno, Y. Requirements for modeling of a snowdrift. Cold Reg. Sci. Technol. 1984, 8, 241-252. [CrossRef]

23. Smedley, D.J.; Kwok, K.C.S.; Kim, D.H. Snowdrifting simulation around Davis Station workshop, Antarctica. J. Wind Eng. Ind. Aerodyn. 1993, 50, 153-162. [CrossRef]

24. Yukawa, T.; Tsutsumi, T.; Taniguchi, N.; Tomabechi, T. Snow accumulation on residential area in snowy cold region. AIJ J. Technol. Des. 2012, 18, 1013-1017. [CrossRef]

25. Mitsuhashi, H. Snowdrifting on building and wind tunnel experiment using model snow. J. Jpn. Soc. Snow Ice 2003, 65, 287-295. [CrossRef]

26. Yukawa, T.; Taniguchi, N.; Tomabechi, T. Study on snow sedimentation area and the area planning of detached houses in snow and cold region. J. Arch. Plan. 2010, 75, 781-786. [CrossRef]

27. Setoguchi, T. Efficiencies of Infill Developments against Snow Problem in Winter Cities-The Snow Simulations for Desirable Block Designs Using Wind Tunnel. J. Asian Arch. Build. Eng. 2004, 3, 335-340. [CrossRef]

28. Setoguchi, T. New urban design approaches with snow simulations for cold and snowy cities. J. Asian Arch. Build. Eng. 2008, 7, 93-99. [CrossRef] 
29. Setoguchi, T.; Tsutsumi, T.; Takakura, M.; Matsuoka, Y.; Oyanagi, Y. Urban design guidelines for the urban complex redevelopment project provided from environmental assessments with snow and wind simulations: The new urban design approaches with snow and wind environmental assessments for snow and cold regions. J. Arch. Plan. 2006, 71, 131-138. [CrossRef]

30. Setoguchi, T.; Tsutsumi, T. Snow and wind environmental assessment on the public space comparing high-rise and medium-rise building blocks using the wind tunnel simulation. J. Arch. Plan. 2007, 72, 167-174. [CrossRef]

31. Setoguchi, T.; Tsutsumi, T. The comparison of snow and wind impacts between high-rise and medium-rise building blocks using the wind tunnel simulation for snow and cold cities. J. Arch. Plan. 2007, 72, 101-108. [CrossRef]

32. Setoguchi, T.; Satoh, K.; Watanabe, N.; Tsutsumi, T. The urban design assessments for the relationship between urban envelope and snow remove energy using snow and wind simulations in snowy and cold cities. J. Arch. Plan. 2012, 77, 2789-2798. [CrossRef]

33. Watanabe, N.; Setoguchi, T.; Sato, K.; Tsutsumi, T. New city block design approaches incorporating environmental assessment for downtown districts in cities with severe winter climates. J. Asian Arch. Build. Eng. 2016, 15, 455-462. [CrossRef]

34. Nishio, F.; Ishida, T. Rate of turbulent energy dissipation during snow drifting. Low Temp. Sci. Ser. A Phys. Sci. 1973, 31, 69-85.

35. Tomabechi, T.; Ueda, H. The applicability of using model snow with wind-tunnel experiments: Part2 Relation between snowdrift formation and frictional stress. In Proceedings of the AIJ Hokkaido Architectural Research Conference, Otaru, Japan, 23 March 1994; pp. 69-72.

36. Oikawa, S.; Tomabechi, T.; Ishihara, T. One-day observations of snowdrifts around a model cube. J. Snow Eng. Jpn. 1999, 15, 283-291. [CrossRef]

37. Oikawa, S.; Tomabechi, T.; Ishihara, T. Study of wind tunnel similarity on snowdrift around buildings. J. Snow Eng. Jpn. 2007, 23, 133-152. [CrossRef]

38. Tsuchiya, M.; Tomabechi, T.; Hongo, T.; Ueda, H. Characteristics of wind flow acting on snowdrift on a stepped flat roof. J. Struct. Constr. Eng. 2002, 67, 53-59. [CrossRef]

39. Tsutsumi, T. Issues of snowdrifts around buildings. Wind Eng. JAWE 2012, 37, 4-9. [CrossRef]

40. Kubota, T.; Miura, M.; Tominaga, Y.; Mochida, A. Wind tunnel tests on the nature of regional wind flow in the $270 \mathrm{~m}$ square residential area, using the real model Effects of arrangement and structural patterns of buildings on the nature of regional wind flow part 1. J. Arch. Plan. Environ. Eng. 2000, 65, 109-116. [CrossRef]

41. Emori, I.; Saito, K.; Sekimoto, K. Mokeijikken no Riron to Ouyou (Theory and Application of Model Experiments), 3rd ed.; Hakuhodo: Tokyo, Japan, 2000; pp. 2-43.

42. Demographic Yearbook 2013 (United Nations). Available online: https:/ / unstats.un.org/unsd/demographic/ products/dyb/dybsets / 2013.pdf (accessed on 5 October 2017).

43. NNDC Climate Data Online (NOAA). Available online: https:/ /www7.ncdc.noaa.gov/CDO/cdo (accessed on 5 October 2017).

44. Weather Online Ltd. Meteorological Services. Available online: http:/ /www.weatheronline.co.uk/about/ About.htm (accessed on 5 October 2017).

45. Weatherbase. Available online: http://www.weatherbase.com/about.php3 (accessed on 5 October 2017).

46. Japan Meteorological Agency, Past Weather Data. Available online: http://www.data.jma.go.jp/obd/stats/ etrn/index.php (accessed on 5 October 2017).

47. Sapporo Urban Community Development Plan. Available online: http://www.city.sapporo.jp/kikaku/ downtown/plan/documents/senryaku.pdf (accessed on 5 October 2017).

(C) 2017 by the authors. Licensee MDPI, Basel, Switzerland. This article is an open access article distributed under the terms and conditions of the Creative Commons Attribution (CC BY) license (http:/ / creativecommons.org/licenses/by/4.0/). 